\title{
Total Petroleum Hydrocarbons content of Taylor Creek, Rivers State, Niger Delta Nigeria
}

\author{
Edori, E. S*, Marcus, A. C. \\ Department of Chemistry, Faculty of Natural and Applied Sciences, Ignatius Ajuru University of Education, \\ Rumuolumeni, PMB 5047 Port Harcourt, Rivers State NIGERIA.
}

*Corresponding Author: Edori, E. S Department of Chemistry, Faculty of Natural and Applied Sciences, Ignatius Ajuru University of Education, Rumuolumeni, PMB 5047 Port Harcourt, Rivers State NIGERIA.

\begin{abstract}
Randomly collected samples from four stations in Tailor Creek sediment in Engenni axis, Ahoada West, Rivers State for a period of four months were analyzed to ascertain the level of pollution and contamination. Extraction of the sample was achieved by soxhlet and cleanup for column chromatography. Total petroleum hydrocarbons were then determined by gas chromatography-flame ionization detection (GCFID). The results revealed a total petroleum hydrocarbon contamination range of 18.035 $\pm 3.527-$ $30.768 \pm 10.850 \mathrm{ml} / \mathrm{Kg}$ in the selected months and $16.192 \pm 6.828-34.790 \pm 12.954 \mathrm{ml} / \mathrm{Kg}$ for the stations. The concentration levels of total petroleum hydrocarbon in sediment samples were well within acceptable limits of FMW and EGAPSIN. Findings from the study showed evidence of slight contamination and pollution. The Taylor Creek therefore needs remediation at this early stage to forestall adverse health effect on humans and other water dwelling organisms.
\end{abstract}

Keywords: Total petroleum hydrocarbon, sediment, Tailor Creek. Pollution, contamination, gas chromatography - flame ionization detector.

\section{INTRODUCTION}

The aquatic environment is under threat due to pollution. As a result of the activities of man, water quality is now subject to question in Niger Delta communities which hosts multinational Oil Companies. It is a known fact that there are certain qualities of water that are used to establish the index or fitness for its consumption (Iyama and Edori, 2014). These qualities are used in assessing the status of any given river to ascertain its usefulness to humans. The presence of these parameters at certain levels affect the status of rivers/ other water bodies and their qualities. Any water quality to be properly assessed must be based on its chemical, biological and physical contents (Lindsey et al., 2005; Lawson, 2011; Iyama and Edori, 2014,).

The rivers or water bodies receive hydrocarbons through prospecting activities and pollution due to illegal refining activities, pipeline explosion, and vandalization, runoffs, leakages from tanks etc., which bring about the greater effect on the nutritional, domestic, economic, ecological and recreational services the rivers offer to the inhabitants of these communities (Isibor and Freeman, 2016, Inyang et al., 2018). The effect of pollution due to hydrocarbons in the rivers of the Niger Delta region of Nigeria is alarming; studies have revealed that petroleum hydrocarbons are potentially harmful and toxic to humans and other organisms that occupy the aquatic space (Barry 2007, Gay et al., 2010). Some human health implications and effects due to petroleum hydrocarbons include, defect at birth, skin rashes, skin irritation, miscarriages and possibly infertility in women, effect on respiratory system, cancer of the different organs of the body etc. (Hurtig and San Sebastian, 2002; Aguilera, 2010; Sudakin et al., 2011; Olawoyin et al., 2012; Ezekwe and Edoqhotu, 2015).

Total petroleum hydrocarbon is a mixture comprising different hydrocarbons in crude oil. The carbon chain of total petroleum hydrocarbons ranges between $\mathrm{C}_{6}-\mathrm{C}_{35}$ and do not occur in one single sample. Total petroleum hydrocarbon compounds are known common pollutants or contaminants of the environment where oil production and exploitation take place (Dibofori- Orji et al., 2018; Alagoa et al., 2018). The presence of total petroleum hydrocarbon even at low concentration of $0.1 \mathrm{ppm}$ has acute toxic effect on marine larvae (USEPA, 1986), and also little quantity of crude oil when in 
contact with sea-water can hinder the actual fish life in the water by affecting its feeding habits (Connell and Miller, 1980). The presence of hydrocarbon fractions such as polycyclic and aromatic hydrocarbons when dissolved in water can be absorbed by some water dwelling creatures due to the fact that they have high level of lipid solubility and can be bio-accumulated in fish and shellfish (Variance and Malins, 1977; Vandermeulen et al., 1985; Al-shwafi, 2008).

Although petroleum hydrocarbon may occur naturally in the environment such as the marine sediment at very low concentrations, large volumes come from the activities of man. The sediment (bottom) of any river is the habitat of many water dwelling or aquatic creatures and it is the reservoir of petroleum hydrocarbons where the high risk of bioaccumulation and concentration on the organisms is high (Filho et al., 2013). Bottom sediment dwelling creatures are greatly affected by petroleum fractions when it is settled at the bottom of the river or creek. These creatures are killed when they cannot swim away, due to the reduction of oxygen which characterizes the presence of petroleum hydrocarbons. Bottom dwelling creatures also accumulate petroleum hydrocarbons through feeding at the bottom of the river, and this results in reduction and loss of important water living organism especially those living at the bottom (Wanat et al., 2007; Ogeleka et al., 2016). This study therefore on the sediment of Taylor Creek in the Niger Delta is predicated upon the above facts in order to ascertain the level of contamination due to the prevalence of oil prospects and other illegal activities.

This study therefore, investigated the concentration of total petroleum hydrocarbons in the sediment of Taylor Creek, an important creek in the Niger Delta.

\section{Materials AND MethodS}

\subsection{Study Area and Description of Sample Location}

The Tailor Creek is a fresh water that is subject to flooding annually. The Creek flows from its course, the Orashi River through Biseni clan in Bayelsa State to Edagberi axis in Engenni, Ahoada West, Rivers State, Zarama and Okordia villages in Yenagoa Local Government Area of Bayelsa State and finally empties itself into River Nun. The inhabitants occupying the area covered by the Creek are mostly fisherman and peasant farmers.

The study sites were located around $6^{\circ} 29^{\prime} 18.7^{\prime \prime} \mathrm{E}$ and $6^{\circ} 30^{\prime} 20.5 \mathrm{E}$ and $5^{\circ} 10^{\prime} 35.8^{\prime \prime} \mathrm{N}$ and $5^{\circ} 11^{\prime} 1.2$ 'N. Four sampling points (stations) were chosen along the creek for the collection of sediment samples. A distance of 1-2 Km was used as gap separating one station from the other at the Edagberi - Better land axis of the creek. The various communities along the shore of the creek play host to the Shell Petroleum Development Company (SPDC). Other activities peculiar to the area include road construction or repair at intervals, illegal oil business/ activities, petty trading etc.

\subsection{Sample Collection}

With the use of a core sediment grab sampler, sediments samples were collected between $5 \mathrm{~cm}$ to $10 \mathrm{~cm}$. Five sediment samples were collected at each sampling location and pooled together to form composite of $400 \mathrm{~g}$. the samples were kept in a plain clear glass bottle previously washed to avoid contamination, and kept at $4{ }^{\circ} \mathrm{C}$, in an ice pack for total petroleum hydrocarbon analysis. The procedure was repeated for each sample station/location. The sediment was then transported to the laboratory for analysis within two (2) weeks of collection.

\subsection{Extraction And Clean Up Procedure of Sediment Sample}

The composite sample was air dried and $120 \mathrm{~g}$ was weighed. The sample were filtered after being properly sieved and homogenized; was then loaded to a soxhlet extractor with the aid of a thimble. Dichloromethane is used as the solvent for extraction. After a period of 24hours the extract was collected and then concentrated using a rotary evaporator at $40^{\circ} \mathrm{C}$. Previously weighed bottles were used to collect the extract and then evaporated to dryness for column chromatography clean-up (Saari et al, 2007).

The clean-up was achieved by putting the extract into a $10 \mathrm{~mm}$ ID by $30 \mathrm{~cm}$ column that is packed with gel (silica) and slurred with anhydrous sulphate layer of $2 \mathrm{~cm}$ at the top. To obtain the total hydrocarbon fractions, the column was eluted with $30 \mathrm{ml}$ of $\mathrm{n}$-hexane. A rotary evaporator at $40^{\circ} \mathrm{c}$ was used to evaporate the sample to dryness and the eluates concentrated to $3 \mathrm{ml}$. The sediment samples were treated by the method of Maioli et al., (2011). 


\subsection{Sample Analysis Using Gas Chromatography}

The sample extracts were analyzed using Agilent 5890 Gas Chromatography with flame Ionization Detector (GC - FID). $3 \mathrm{ml}$ of the concentrated extract was used to determine the concentration of total petroleum hydrocarbon in the sediment samples. The temperature of the detector was kept at $400^{\circ} \mathrm{C}$ and the aliphatic and the aromatic hydrocarbon in the samples are measured by the GC-FID, to give the total petroleum hydrocarbon concentration.

\subsection{Statiscal Analysis}

The resultsobtained were reported as mean \pm standard deviation and were subjected to student's $t-$ test in order to compare between means. The obtained data were replicated in triplicates, and analysis of variance (ANOVA) was then used to test more than two means to see whether there is a significant difference between the sample stations and months.

\section{RESULTS AND DISCUSSION}

The level of contamination by total petroleum hydrocarbon in the sediment of Taylor Creek are shown in Tables 1 to 4. Most river pollutants found themselves at the bottom part of the river and therefore the bottom (sediment) is the residue or sink for pollutants in the rivers of the Niger Delta region of Nigeria and elsewhere in the world (Inyang et al., 2018). Table 1 showed the levels of contamination for the month of December, Table 2, for February, Table 3 for April and Table 4 for June. The concentration levels of pollution in Table 1 are: station $1 ; 11.45118 \mathrm{ml} / \mathrm{Kg}$, station $2 ; 36.06666 \mathrm{ml} / \mathrm{Kg}$, station 3;8.33891ml/Kg and station $4 ; 22.97539 \mathrm{ml} / \mathrm{Kg}$, in February, the level of total petroleum hydrocarbon contamination in the stations are $23.05472 \mathrm{ml} / \mathrm{Kg}, 13.45606 \mathrm{ml} / \mathrm{Kg} .16 .4935 \mathrm{ml} / \mathrm{Kg}$ and $19.13457 \mathrm{ml} / \mathrm{Kg}$ respectively for station 1,2,3 and 4. In April the result showed contamination level of $7.5571544 \mathrm{ml} / \mathrm{Kg}, 42.23962 \mathrm{ml} / \mathrm{Kg}, 24.27905 \mathrm{ml} / \mathrm{Kg}$ and $20.49308 \mathrm{ml} / \mathrm{Kg}$, for station 1 to 4 and in June, the level of hydrocarbon recorded in 1 is $22.69754 \mathrm{ml} / \mathrm{Kg}$, station $2 ; 47.39567 \mathrm{ml} / \mathrm{Kg}$, station 3; $33.29445 \mathrm{ml} / \mathrm{Kg}$ and station $4 ; 19.682 \mathrm{ml} / \mathrm{kg}$. The concentration levels of the various stations do not follow any special pattern. This is because there is no activity in any particular station that is completely different from the others.

Table1. Total Petroleum Hydrocarbon concentrations in Sediments of Taylor Creek in December.

\begin{tabular}{|c|c|c|c|c|}
\hline \multirow{2}{*}{$\begin{array}{l}\text { Carbon Length } \\
(\mathrm{ml} / \mathrm{L})\end{array}$} & \multicolumn{4}{|c|}{ Stations } \\
\hline & 1 & 2 & 3 & 4 \\
\hline $\mathrm{C} 8$ & - & - & - & 0.68179 \\
\hline C9 & - & - & - & - \\
\hline $\mathrm{C} 10$ & - & - & - & - \\
\hline C11 & - & - & - & - \\
\hline $\mathrm{C} 12$ & - & - & - & - \\
\hline $\mathrm{C} 13$ & - & - & - & 0.42192 \\
\hline $\mathrm{C} 14$ & - & - & 0.85751 & 2.24375 \\
\hline $\mathrm{C} 15$ & - & - & 2.09457 & 3.35482 \\
\hline $\mathrm{C} 16$ & 1.90596 & 1.59649 & 0.84269 & - \\
\hline $\mathrm{C} 17$ & 2.88204 & - & 1.51575 & 0.68339 \\
\hline $\mathrm{C} 18$ & - & 0.84386 & 1.51575 & 0.96286 \\
\hline $\mathrm{C} 19$ & - & 0.96028 & 0.68167 & 0.46042 \\
\hline $\mathrm{C} 20$ & 1.80313 & 1.03125 & 2.20175 & 2.48963 \\
\hline $\mathrm{C} 21$ & - & - & - & - \\
\hline $\mathrm{C} 22$ & 3.57061 & 0.47890 & 0.32078 & 0.17433 \\
\hline $\mathrm{C} 23$ & - & - & - & - \\
\hline $\mathrm{C} 24$ & 4.31379 & 1.50851 & 1.00659 & 2.48305 \\
\hline $\mathrm{C} 25$ & - & - & - & - \\
\hline $\mathrm{C} 26$ & 0.56147 & -2.66966 & 0.94532 & 0.01370 \\
\hline $\mathrm{C} 27$ & - & - & - & - \\
\hline $\mathrm{C} 28$ & 0.52271 & 0.05474 & 2.59422 & 1.99679 \\
\hline $\mathrm{C} 29$ & - & - & - & - \\
\hline $\mathrm{C} 30$ & 0.27017 & 2.49588 & 1.91691 & 0.01121 \\
\hline $\mathrm{C} 31$ & - & - & - & - \\
\hline $\mathrm{C} 32$ & 4.60086 & 1.81649 & - & 2.68096 \\
\hline $\mathrm{C} 33$ & - & - & - & - \\
\hline C34 & 2.62398 & - & - & 0.47595 \\
\hline $\mathrm{C} 35$ & - & - & - & - \\
\hline C36 & 1.28727 & - & - & - \\
\hline
\end{tabular}


Total Petroleum Hydrocarbons content of Taylor Creek, Rivers State, Niger Delta Nigeria

\begin{tabular}{|c|c|c|c|c|}
\hline C37 & - & - & - & - \\
\hline $\mathrm{C} 38$ & - & - & - & - \\
\hline C39 & - & - & - & - \\
\hline $\mathrm{C} 40$ & - & - & - & - \\
\hline Total & 23.05472 & 13.45606 & 16.49351 & 19.13457 \\
\hline
\end{tabular}

Table2. Total Petroleum Hydrocarbon concentrations in Sediments of Taylor Creek in February.

\begin{tabular}{|c|c|c|c|c|}
\hline \multirow{2}{*}{$\begin{array}{l}\text { Carbon Length } \\
(\mathrm{ml} / \mathrm{L})\end{array}$} & \multicolumn{4}{|c|}{ Stations } \\
\hline & 1 & 2 & 3 & 4 \\
\hline $\mathrm{C} 8$ & - & - & - & - \\
\hline C9 & - & 8.98843 & & - \\
\hline C10 & - & 6.82417 & - & - \\
\hline $\mathrm{C} 11$ & - & 4.76341 & - & - \\
\hline $\mathrm{C} 12$ & - & - & - & - \\
\hline $\mathrm{C} 13$ & - & 8.23466 & - & - \\
\hline $\mathrm{C} 14$ & - & 7.25599 & - & - \\
\hline C15 & - & - & - & - \\
\hline $\mathrm{C} 16$ & - & - & - & - \\
\hline C17 & - & - & - & - \\
\hline C18 & - & - & 2.65205 & - \\
\hline C19 & 2.26369 & - & 3.18332 & 0.89696 \\
\hline $\mathrm{C} 20$ & 0.83269 & - & - & 1.88716 \\
\hline $\mathrm{C} 21$ & - & - & - & - \\
\hline $\mathrm{C} 22$ & 0.02004 & - & - & \\
\hline $\mathrm{C} 23$ & - & - & - & - \\
\hline $\mathrm{C} 24$ & 2.07098 & - & - & 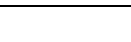 \\
\hline $\mathrm{C} 25$ & - & - & - & - \\
\hline $\mathrm{C} 26$ & 2.37404 & - & 0.14786 & 20.19127 \\
\hline $\mathrm{C} 27$ & - & - & - & - \\
\hline $\mathrm{C} 28$ & 1.76548 & - & 2.27664 & \\
\hline $\mathrm{C} 29$ & - & - & - & - \\
\hline $\mathrm{C} 30$ & 0.41673 & & 0.07904 & \\
\hline C31 & - & - & - & - \\
\hline $\mathrm{C} 32$ & 1.75753 & & - & - \\
\hline C33 & - & - & - & - \\
\hline C34 & - & & - & - \\
\hline $\mathrm{C} 35$ & - & - & - & - \\
\hline C36 & - & & - & - \\
\hline C37 & - & - & - & - \\
\hline C38 & - & - & - & - \\
\hline C39 & - & - & - & - \\
\hline $\mathrm{C} 40$ & - & - & - & - \\
\hline Total & 11.45118 & 36.06666 & 8.33891 & 22.97539 \\
\hline
\end{tabular}

Table3. Total Petroleum Hydrocarbon concentrations in Sediments of Taylor Creek in April.

\begin{tabular}{|l|c|c|c|c|}
\hline \multirow{2}{*}{\begin{tabular}{l} 
Carbon Length $(\mathrm{ml} / \mathrm{L})$ \\
\cline { 2 - 5 }
\end{tabular}} & 1 & 2 & 3 & \multicolumn{2}{|c|}{ Stations } \\
\hline C8 & 0.83414 & - & - & 10.81285 \\
\hline C9 & 1.19628 & - & - & 1.11381 \\
\hline C10 & 1.24472 & - & - & 1.10252 \\
\hline C11 & 0.46615 & - & - & 0.21970 \\
\hline C12 & 0.00458 & - & - & 3.77484 \\
\hline C13 & 3.49602 & - & 2.91768 & 0.28450 \\
\hline C14 & 0.17873 & - & 1.75378 & 0.040040 \\
\hline C15 & 0.053307 & - & 0.94128 & - \\
\hline C16 & - & - & 1.62440 & - \\
\hline C17 & - & - & 0.70540 & - \\
\hline C18 & - & - & 4.23102 & - \\
\hline C19 & - & 0.95387 & 3.95617 & - \\
\hline C20 & - & -44019 & - & - \\
\hline C21 & - & - & 1.92770 & - \\
\hline C22 & - & - & - & - \\
\hline C23 & - & - & 2.62502 & 0.0082283 \\
\hline C24 & & & \\
\hline
\end{tabular}


Total Petroleum Hydrocarbons content of Taylor Creek, Rivers State, Niger Delta Nigeria

\begin{tabular}{|l|c|c|c|c|}
\hline \multicolumn{1}{|c|}{ C25 } & - & - & - & - \\
\hline C26 & 0.0209087 & 37.84556 & - & 0.0713792 \\
\hline C27 & - & - & - & 0.0277949 \\
\hline C28 & - & - & - & 0.0442824 \\
\hline C29 & - & - & 3.59668 & 0.0620886 \\
\hline C30 & 0.0623183 & - & - & 0.0750028 \\
\hline C31 & - & - & - & 0.0816718 \\
\hline C32 & - & - & - & - \\
\hline C33 & - & - & - & 0.0290676 \\
\hline C34 & - & - & - & 0.105238 \\
\hline C35 & - & - & - & 0.0289019 \\
\hline C36 & - & - & - & 0.113339 \\
\hline C37 & - & - & - & - \\
\hline C38 & - & - & - & 0.190881 \\
\hline C39 & - & 42.23962 & 24.27905 & - \\
\hline C40 & 7.5571544 & & - & 20.4939308 \\
\hline Total & & - & - & - \\
\hline
\end{tabular}

Table4. Total Petroleum Hydrocarbon concentrations in Sediments of Taylor Creek in June.

\begin{tabular}{|c|c|c|c|c|}
\hline \multirow{2}{*}{$\begin{array}{l}\text { Carbon Length } \\
(\mathrm{ml} / \mathrm{L})\end{array}$} & \multicolumn{4}{|c|}{ Stations } \\
\hline & 1 & 2 & 3 & 4 \\
\hline C8 & - & 1.48533 & - & - \\
\hline C9 & - & 2.34464 & - & - \\
\hline $\mathrm{C} 10$ & - & 3.40226 & - & - \\
\hline $\mathrm{C} 11$ & - & 2.81943 & - & - \\
\hline $\mathrm{C} 12$ & - & 1.60829 & - & - \\
\hline $\mathrm{C} 13$ & - & - & - & - \\
\hline $\mathrm{C} 14$ & - & 5.15724 & - & - \\
\hline $\mathrm{C} 15$ & 3.22017 & 1.79875 & - & - \\
\hline $\mathrm{C} 16$ & 0.72638 & 5.50333 & - & - \\
\hline $\mathrm{C} 17$ & 0.41828 & - & - & - \\
\hline $\mathrm{C} 18$ & 0.97050 & 1.96170 & 21.21699 & - \\
\hline C19 & 0.32856 & 15.70324 & 7.20371 & - \\
\hline $\mathrm{C} 20$ & 0.03276 & - & 2.15885 & - \\
\hline $\mathrm{C} 21$ & - & - & - & - \\
\hline $\mathrm{C} 22$ & 2.13401 & 2.14022 & - & - \\
\hline $\mathrm{C} 23$ & - & - & - & - \\
\hline $\mathrm{C} 24$ & 3.79484 & 1.73562 & 2.71490 & 13.35548 \\
\hline $\mathrm{C} 25$ & - & - & - & - \\
\hline $\mathrm{C} 26$ & 4.45071 & 1.73562 & - & 3.36848 \\
\hline $\mathrm{C} 27$ & - & - & - & - \\
\hline $\mathrm{C} 28$ & 0.87481 & - & - & - \\
\hline $\mathrm{C} 29$ & - & - & - & - \\
\hline C30 & 0.05274 & - & - & 2.95805 \\
\hline C31 & - & - & - & - \\
\hline C32 & 0.96429 & - & - & - \\
\hline C33 & - & - & - & - \\
\hline C34 & 4.72949 & - & - & - \\
\hline C35 & - & - & - & - \\
\hline C36 & - & - & - & - \\
\hline C37 & - & - & - & - \\
\hline C38 & - & - & - & - \\
\hline C39 & - & - & - & - \\
\hline $\mathrm{C} 40$ & - & - & - & - \\
\hline Total & 22.69754 & 47.39567 & 33.29445 & 19.682 \\
\hline
\end{tabular}

Tables 5 and 6 showed the total and mean concentration of total petroleum hydrocarbon for the months of December, February, April and June. The result in December showed $94.5689044 \mathrm{ml} / \mathrm{Kg}$ as total and $23.6422261 \mathrm{ml} / \mathrm{Kg}$, in February, $78.83214 \mathrm{ml} / \mathrm{Kg}$ and $19.708035 \mathrm{ml} / \mathrm{Kg}$ as total and mean values respectively. Total and mean concentration values for April were $72.13886 \mathrm{ml} / \mathrm{kg}$ and 
$18.034715 \mathrm{ml} / \mathrm{kg}$, in June, the concentration values for total and mean hydrocarbons in sediment were $123.06986 \mathrm{ml} / \mathrm{kg}$ and $30.767465 \mathrm{ml} / \mathrm{kg}$ respectively. The total and mean concentrations of total petroleum hydrocarbons for the stations were $64.7605944 \mathrm{ml} / \mathrm{Kg}$ and $16.1901486 \mathrm{ml} / \mathrm{Kg}$ for station 1 , $139.15801 \mathrm{ml} / \mathrm{Kg}$ and $34.7895 .25 \mathrm{ml} / \mathrm{Kg}$ for station $2,82.40592 \mathrm{ml} / \mathrm{kg}$ and $20.60148 \mathrm{ml} / \mathrm{kg}$ for station 3 and $82.28504 \mathrm{ml} / \mathrm{Kg}$ and $20.57126 \mathrm{ml} / \mathrm{Kg}$ for station 4 .

The values obtained for mean total petroleum hydrocarbons for the sediment samples in the months and stations are below or equal to the allowable (accepted) value by Federal Ministry Environment (FME) (1991) OF 30mg/kg and EGASPIN (Environmental Guidelines and Standard for the petroleum industry in Nigeria (2002) for sediment samples for $(50 \mathrm{mg} / \mathrm{Kg}$ ) and except station 2, which is slightly above the permissible limit of FME with mean value of $34.7895025 \mathrm{mg} / \mathrm{Kg}$. The mean total petroleum hydrocarbon concentration in the study fall far below what was reported by Adewuyi et al., (2011) of $1602.4 \pm 8.9 \mathrm{mg} / \mathrm{Kg}$; that obtained from from Ubeji River in Warri, Nigeria, by Samuel and Ayodele, (2014), which recorded high value of $41900 \mathrm{mg} / \mathrm{Kg}$ from Benin river which is close to an oil factory. Inyanget al., (2018) also had a mean sediment value of $606.83 \pm 229.48 \mathrm{mg} / \mathrm{Kg}$ in Qua-Iboe River, which is higher than the ones obtained in this study. The average value of total hydrocarbon content also is lower than those elsewhere in other parts of the world, such as in the sediment of the Victoria harbor, Hong Kong of $60-646 \mathrm{mg} / \mathrm{g}$ (Hong et al, 1995) in the Bapco oil coastline that is highly contaminated around the refinery in Bahrain which is $779 \mathrm{mg} / \mathrm{g}$ (Tolose et al., 2005).

The results from the creek though when compared to other rivers of the Niger Delta region of Nigeria and other parts of the world seem low, but may pose danger to benthic organisms (Monazami Tehrani et al., 2014), if proper measures are not taken into account. The behaviour of freshwater is different from that of brackish or tidal water. The flow is unidirectional, and when contamination is with total petroleum hydrocarbons as a result of spills or otherwise, the system has purifying measures that does not support accumulation. The rapid flowing mechanism help the petroleum fractions that is spilled into the creek to dissolve and thereby restricting much evaporation of the volatile fractions (Aremu, 1998; Adewuyi et al., 2011; Marcus etal., 2013). During months of flood, the creek over-flow its bank thereby depositing the petroleum hydrocarbons in the adjoining farmland, tree tops, and any other point the flood can take it to. The process does not allow sedimentation of hydrocarbon fraction, but re-suspends them from the sediment and drifts them away to the point where it finally flows into.

The pollution and contamination make the water source and the adjoining farmlands less useful to the inhabitants of such environments. Fishing and farming which is the main stay of the inhabitant becomes a difficult task due to the negative impact the contamination has posed on the people (Ite et al., 2016). The development of illegal oil activities has also increasingly impacted negatively on the health status of the dwellers since, the adjoining creek is used for domestic works, recreation, fishing etc. the presence of total petroleum hydrocarbon in the sediment of the creek may also pose danger to the ecosystem within the region of study.

Table 5. Mean Bimonthly Concentrations $(\mathrm{ml} / \mathrm{L})$ of Total Petroleum Hydrocarbons in Sediments at the different Stations

\begin{tabular}{|c|c|c|c|c|}
\hline \multirow{2}{*}{ Stations } & \multicolumn{4}{|c|}{ Months } \\
\cline { 2 - 5 } & December & February & April & June \\
\hline 1 & 7.557 & 11.451 & 23.055 & 47.698 \\
\hline 2 & 42.240 & 36.067 & 13.456 & 33.294 \\
\hline 3 & 24.279 & 8.339 & 16.494 & 19.682 \\
\hline 4 & 20.493 & 22.975 & 19.135 & 123.070 \\
\hline Total & 94.569 & 78.832 & 72.140 & $30.768 \pm 10.850$ \\
\hline Mean & $23.642 \pm 12.399$ & $19.708 \pm 10.905$ & $18.035 \pm 3.527$ & \\
\hline
\end{tabular}

Table6. Mean Spatial (Station) Variation of Total Petroleum Concentrations $(\mathrm{ml} / \mathrm{L})$ in Sediments within the examined Months

\begin{tabular}{|c|c|c|c|c|}
\hline \multirow{2}{*}{ Stations } & \multicolumn{4}{|c|}{ Months } \\
\cline { 2 - 5 } & 1 & 2 & 3 & 4 \\
\hline December & 7.557 & 42.240 & 24.279 & 20.493 \\
\hline February & 11.451 & 36.067 & 8.339 & 22.975 \\
\hline April & 23.055 & 13.456 & 16.494 & 19.135 \\
\hline June & 22.698 & 47.396 & 33.294 & 19.682 \\
\hline Total & 64.761 & 139.158 & 82.406 & 82.285 \\
\hline Mean & $16.192 \pm 6.828$ & $34.790 \pm 12.954$ & $20.602 \pm 9.245$ & $20.571 \pm 1.470$ \\
\hline
\end{tabular}




\section{CONCLUSION}

The study showed that there is a degree of contamination of the Taylor Creek, though not yet at an alarming stage. The conclusion was reached based on the fact that certain level of total petroleum hydrocarbon concentration was found in the sediment of the Creek. There should be effective monitoring of the Creek by the relevant government agencies to forestall any further increase of total petroleum hydrocarbon in the Creek. Human dweller should be discouraged from pouring petroleum product to the Creek directly. The water in the Creek should not be used for drinking, bathing and other purpose that may affect human health.

\section{REFERENCES}

[1] Adewuyi, G. O., Etchie, O. T. and Ademoyegun, O. T. (2011). Determination of total petroleum hydrocarbons and heavy metals in surface water and sediment of Ubeji River, Warri, Nigeria. Bioremediation, Biodiversity, andbioavailability, 5(1): 46-51.

[2] Alagoa, K. J., Godwin, J., Daworiye, P. S. and Ipiteikumoh, B. (2018). Evaluation of total petroleum hydrocarbon (TPH) in sediments and aquatic macrophytes in the River Nun, Amasoma Axises, Niger Delta, Nigeria. International Journal of Environmental and Agriculture Research, 4(2): 63-67.

[3] Al-Shwafi, N. A. A. (2008). Total petroleum hydrocarbon carcinogens in commercial fish in the Red Sea and Gulf of Aden-Yemen. MarineScience, 19: 15-28.

[4] Aqilera, F., Mendez, J., Pasaro, E. and Laffon, B. (2010). Review on the effects of exposure to spilled oils on human health. Journal of Applied Toxicology, 30(5): 1021-1027.

[5] Aremu, D. A. (1998). Impact of petroleum industry operations in groundwater quality in Warri. $\mathrm{PhD}$ thesis, EMSEH, Public Health. University of Ibadan, 210pp.

[6] Barry, C. (2007). Slick death: Oil-spill treatment kills coral. ScienceNews, 171: 67.

[7] Connell, D. W. and Miller, D. J. (1980). Petroleum hydrocarbons in aquatic ecosystem-behaviour and effect of sublethal concentrations. Part 2, CRC Critical Review and Environmental Control, 12: 405-409.

[8] Environmental Guidelines and Standards for the Petroleum Industry in Nigeria (EGASPIN) (2002). Revised edition, Department of Petroleum Resources (DPR), 314.

[9] Ezekwe, C. I. and Edoghotu, M. I. (2015). Water quality and environmental health indicators in the Andoni River estuary, Eastern Niger Delta of Nigeria. Environmental Earth Sciences, 74(7): 6123-6136.

[10] Federal Ministy of Environment (FME) (1991). Guidelines and Standards for environmental pollution and control in Nigeria. Nigerian ambient air quality standard.

[11] Filho, S., Luz, J. P., Betemps, G. R., Silva, G and Caramao, B. E. (2013). Studies of n-alkanes in the sediments of colony Z3 (Pelotas-RS-Brazil). Brazil Journal of Aquatic Science and Technology, 17(1): 2733.

[12] Gay, J., Shepherd, O., Thyden, M. and Whitman, M. (2010). The health effects of oil contamination: A compilation of research, Worcester Polytechnic Institute, Worcester, MA, USA.

[13] He, A, E., Ufot, U. F., Ite, M. U. Isaac I. O. and Ibok, U. J. (2016). Petroleum industry in Nigeria, environmental issues, national environmental legislation and implementation of international law. American Journal of Environmental Protection, 491): 21-37.

[14] Hong, H., Xu, L., Zhang, L., Chen, J., Wong, Y. and Wan, T. (1995). Special guest paper: Environmental fate and Chemistry of organic pollutants in the sediment of Xiamen and Victoria Harbours. Marine pollution Bulletin, 31(4-12); 229-2366.

[15] Hurtig, A. K. and San Sebastian, M. (2002). Geographical differences in cancer incidence in the Amazon basin of Ecuador in relation to residence near oil fields. International Journal of Epidemiology, 31(5): 1021-1027.

[16] Isibor, P, O. and Freeman, O. E. (2016). Evaluation of some heavy metal and total petroleum hydrocarbon in water and palaemonid shrimps (Macrobrachium vollenhovenni) of Egboko River, Warri, Delta State, Nigeria.Journal of Applied Life Sciences International, 6(4): 1-12.

[17] Iyama, W. A. and Edori, O. S. (2014). Analysis of the water quality of Imonite Creek in Ndoni,Rivers State, Nigeria. IOSR Journal of Applied Chemistry, 7(1): 6-9.

[18] Inyang, S. E., Aliyu, A. B. and Oyewale, A. O. (2018). Total petroleum hydrocarbon content in sirface water and sediment of Qua-Iboe River, Ibeno, Akwa-Ibom State, Nigeria. Journal of Applied Science and Environmental Management, 22(12): 1953-1959.

[19] Lawson, E. O. (2011). Physico-chemical parameters and heavy metal content of water from the mangrove swamps of Lagos, Lagoon, Lagos, Nigeria. Advances in Biological Research, 5(1): 20-26. 
[20] Lindsey, H. D. M. James, M. M. and Hector, M. (2005). An assessment of metal contamination in mangrove sediments and leaves from Paurita Mala Bay, Pacific Panama. PollutionBulletin, 50:547-552.

[21] Maioli, O. L., Rodrigues, C. K., Knoppers, B. A. and Azevedo, D. (2011). Distribution and sources of aliphatic and polycyclic aromatic hydrocarbons in suspended particulate matter in water from two Brazilian estuarine systems. Cont. Shelf. Res., 31(10): 1116-1127.

[22] Marcus, A. C., Okoye, C. O. B. and Ibeto, C. N. (2018). Environmental pollution quality assessment of the water of Bonny River and Creeks around Okrika in Rivers State, Nigeria. International Journal of Applied Environmental Science, 8(1): 1-11.

[23] Monazami Tehrani, G. H., Rosli, H., Sulaiman, A. H., Tavakoly sany, B., Salleh, A., Owfi, F., Savari, A., Khan Jazani, R. and Monazami Tehrani, Z. H. (2014). Petroleum hydrocarbon assessment in the wastewaters of petrochemical special economic zone and sediment benchmark calculation of the coastal area-northwest of the Persian Gulf. Iranian Journal of Fisheries Sciences, 13(1): 119-135.

[24] Ogeleka, D. F., Edjere, O., Nwudu, A. and Okieimen, F. E. (2016). Ecological effects of oil spill on pelagic and bottom dwelling organisms in the riverine areas of Odidi and Egwa in Warri, Delta State. Journal of Ecology and the Natural Environment, 8(12): 201-211.

[25] Olawoyin,R., Larry Grayson, R. and Okareh, O. T. (2012). Ecological and epidemiological assessment of human exposure to polycyclic aromatic hydrocarbons in the Niger Delta, Nigeria. Toxicology and Environmental Health Sciences, 4(3): 173- 185.

[26] Sudakin, D. L., Stone, D. L. and Power, L. (2011). Naphthalene mothballs: Emerging and recurring issues and their relevance to Environmental health. Current topics in toxicology, 7: 13-19.

[27] Saari, E, Peramaki, P. and Jalonen, J. (2007). A comparative study 0f solvent extraction of total petroleum hydrocarbons in soil. Microchim. Acta., 158(3-4): 261-268.

[28] Samuel, O. A. and Ayodele, R. I. (2014). An assessment of the oil and toxic heavy metal profiles of sediments of the Benin River adjacent to a lubricating oil producing factory, Delta State, Nigeria. International Research Journal of Public and Environmental Health, 1(2): 40-53.

[29] Tolosa, I., De Mora, S. J., Fowler, S. W., Villeneuve, J. P., Bartocci, J. and Cattini, C. (2005). Aliphatic and Aromatic Hydrocarbons in marine biota and coastal sediments from the Gulf and the Gulf Oman. MarinePollutionBulletin, 50(12): 1619-1633.

[30] United States Environmental Protection Agency(USEPA) (1986). Quality criteria for water 1986, US Environmental Protection Agency, Office of water regulations: standard, Washinton, DC, EPA, 440/5-86001.

[31] Vandermeulen, J. H., Foda, A. and Stuttard, C. (1985). Toxic vs mutagenicity of some crude oils distillates and the water-soluble fractions. WaterResearch, 19(10): 1283-1289.

[32] Variance, U. and Malins, D. C. (1977). Metabolism petroleum hydrocarbons: accumulation and biotransformation in marine organisms, In effects of petroleum on Artic and Subartic marine environments and organisms, volume Biological Effects, D. C. Malins (ed), Academic Press, New York, 175-270.

[33] Wanat, Y. Jin, X. H. and Jin, F. (2007). Trophic dilution of polycyclic aromatic hydrocarbon (PAHs) in marine food web from Bohai Bay, North China. Environmental Science and Technology, 41: 3109-3114.

Citation: Edori, E. S, Marcus, A. C., "Total Petroleum Hydrocarbons content of Taylor Creek, Rivers State, Niger Delta Nigeria”, International Journal of Advanced Research in Chemical Science, vol. 6, no. 12, p. 1623, 2019. DOI: http://dx.doi.org/10.20431/2349-0403.0612003

Copyright: (C) 2019 Authors. This is an open-access article distributed under the terms of the Creative Commons Attribution License, which permits unrestricted use, distribution, and reproduction in any medium, provided the original author and source are credited. 